\title{
Studies on Cholinesterase
}

\section{CHOLINESTERASE AND PSEUDO-CHOLINESTERASE}

\author{
By B. MENDEL AND H. RUDNEY, The Banting and Best Department of Medical \\ Research, Banting Institute, University of Toronto, Canada
}

(Received 8 October 1942)

The existence of an enzyme capable of hydrolysing acetylcholine into choline and acetic acid, first suggested by Dale [1914], was established by Loewi \& Navratil [1926] and has since been confirmed by many investigators.

It is still a matter of controversy whether the hydrolysis of acetylcholine is effected by a nonspecific esterase or by a specific enzyme, which acts exclusively on esters of choline. Stedman \& Stedman [1935], regarding the enzyme present in blood serum as the specific catalyst for the hydrolysis of choline esters, named it choline esterase. While not insisting on the absolute substrate specificity of the enzyme, Easson \& Stedman [1937] maintain that cholinesterase is 'specific to the extent that its principal action is to hydrolyse simple esters of choline'. Vahlquist [1935], on the contrary, denies the specificity of cholinesterase in plasma, claiming that the hydrolysis of acetylcholine is brought about by the same enzyme which hydrolyses tributyrin. The specific nature of the enzyme in tissues, on the other hand, has, apparently, not been questioned, the hydrolytic action of tissue extracts on acetylcholine being indiscriminately referred to as 'cholinesterase activity'.

It is the purpose of this paper to show that there exist in the animal body two esterases capable of hydrolysing acetylcholine: a true cholinesterase acting exclusively on choline esters, and a nonspecific enzyme, which hydrolyses not only esters of choline but a variety of non-choline esters as well. Moreover, experiments with both enzymes at high and low concentrations of acetylcholine, have revealed a decisive difference between the two esterases, calling for a sharp distinction of the true cholinesterase from the non-specific enzyme, for which. we venture to suggest the name pseudocholinesterase.

\section{PSEUDO-CHOLINESTERASE}

The following three series of experiments, carried out with extensively purified enzyme preparations, are neither consistent with the conception of the specific nature of the 'cholinesterase' present in blood serum, nor do they support the view that the hydrolysis of choline esters by tissues is invariably due to a specific enzyme.

\section{(a) The action of 'cholinesterase' from serum and pancreas on non-choline esters*}

Horse serum and crude tissue extracts from pancreas (dog) hydrolyse not only esters of choline, but also have a marked hydrolytic effect on non-choline esters such as tributyrin, tripropionin and methyl butyrate. Moderate purification of the 'cholinesterase' from these sources results in a considerable loss of activity towards non-choline esters; but once a hundred-fold increase in 'cholinesterase' activity has been attained, the ratio $Q_{\mathrm{Ach}} / Q_{\text {non-ChE }}$ remains constant upon further purification. Even when the activity of the 'cholinesterase' has been increased about two thousand times this ratio is still the same (Table 1).

A variety of steps is required in order to proceed from a hundred-fold to a two thousand-fold increase in 'cholinesterase' activity. If we assume that two distinct enzymes are present in our hundred-fold purified extracts, the one acting on acetylcholine, the other on non-choline esters, it seems reasonable to expect that the ratio $Q_{\mathrm{Ach}} / Q_{\mathrm{non}-\mathrm{ChE}}$ would change during the process of further purification. The fact that this ratio remains constant suggests that a single enzyme is responsible for the observed choline and non-choline ester hydrolysis. The following experiments verify this hypothesis.

* The method for the purification of the tissue 'cholinesterase' (dog pancreas) used in our experiments will be found in this issue [Mendel \& Mundell, 1943]; the purification of the pseudo-cholinesterase from horse serum will be published later.

The activity of the enzyme preparation was measured manometrically by Warburg's method at $37.5^{\circ}$ in $0.025 M$ $\mathrm{NaHCO}_{3}$ saturated with $5 \% \mathrm{CO}_{2}(p \mathrm{H} \mathrm{7 \cdot 4})$. Each molecule of acid liberated from choline esters or non-choline esters during hydrolysis, releases one molecule of $\mathrm{CO}_{2}$ from the bicarbonate. Therefore, the quotient

$$
\frac{\text { [volume of } \mathrm{CO}_{2} \text { (in } \mu \mathrm{l} \text {.)] }}{\text { [time (in hr.)] } \times \text { [dry-wt. of enzyme preparation (in mg.)] }} \text {, }
$$

which will be denoted by the symbol $Q$, is a measure of the activity of the enzyme preparation. The suffix to $Q$ refers

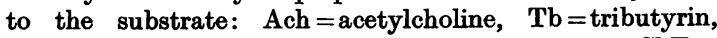
$\mathbf{M b}=$ methyl butyrate, $\mathbf{T p}=$ tripropionin and non-ChE = non-choline esters. 
Table 1. Hydrolysis of choline and non-choline esters by 'cholinesterase' preparations of varying purity

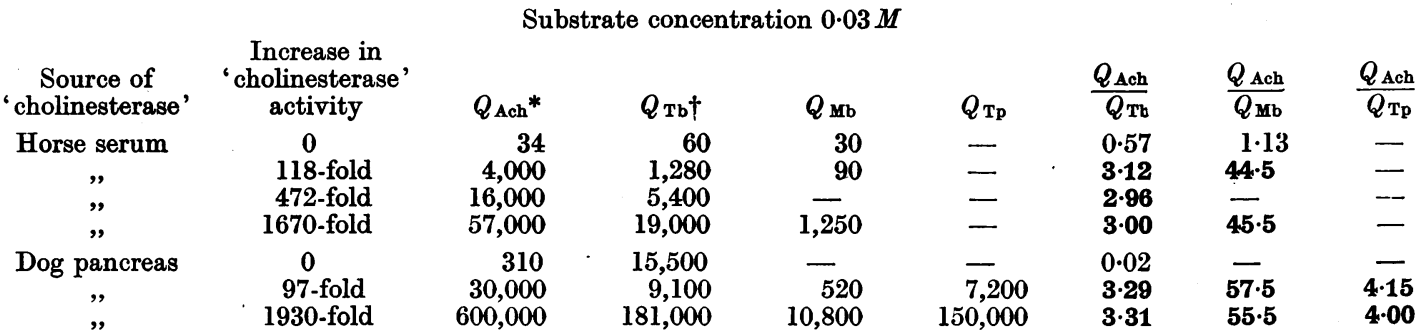

* Acetylcholine chloride (Hoffmann-La Roche) was used in all experiments.

$\dagger$ Since the tributyrin at our disposal contained some inhibitory substance, it was purified by fractionated distillation in a high vacuum $(0.003 \mathrm{~mm}$. $\mathrm{Hg})$. The pure substance distilled at b.p. $97^{\circ}-98^{\circ}$ (bath temperature $\left.135-140^{\circ}\right), n_{D}^{26^{\circ}}=1 \cdot 4340$.

\section{(b) The effect of eserine on choline and non-} choline ester hydrolysis

Easson \& Stedman [1937], experimenting with various blood sera, found that about a thousand times the amount of eserine sufficient for the complete inhibition of choline ester hydrolysis only partially abolished the hydrolysis of non-choline esters.

We are able to confirm these observations, and agree with Stedman's interpretation that a special enzyme, esterase, capable of hydrolysing noncholine esters and scarcely sensitive to eserine, is present in certain untreated sera. As such sera (guinea-pig, horse) and crude tissue extracts (dog pancreas) contain far greater quantities of esterase than of 'cholinesterase' the action of the former would obviously conceal the inhibitory effect of eserine on the activity of the latter towards noncholine esters. choline esters to practically the same extent. Apart from confirming the absence of esterase, these experiments make it highly improbable that two enzymes - the one acting on choline esters, the other on non-choline esters-are present in our purified preparations, thus supporting our hypothesis that the 'cholinesterase' in serum and pancreas is a nonspecific enzyme.

\section{(c) The action of serum and tissue extracts on mixed substrates}

If tissue extracts. or sera contained two enzymes capable of hydrolysing substrates $A$ and $B$ respectively, addition of the activities of both enzymes should occur in the presence of the two substrates, provided the substrate concentrations were optimal and substrate $A$ did not inhibit the hydrolysis of substrate $B$ and vice versa. The latter point has already been dealt with by Stedman [1935], who found that choline esters do not inhibit appreciably,

Table 2. The effect of eserine on the hydrolysis of acetylcholine and tributyrin by purified 'cholinesterase' preparations

$\begin{array}{cc}\text { Source of } & \text { Eserine } \\ \text { 'cholinesterase' } & \text { concentration } \\ \text { preparation } & M \\ \text { Horse serum } & 0 \\ \left(Q_{\text {Ach }} 16,000\right) & 10^{-8} \\ & 10^{-7} \\ \text { Dog pancreas } & 10^{-6} \\ \left(Q_{\text {Ach } 600,000)}\right. & 0 \\ & 10^{-8} \\ & 10^{-7} \\ & 10^{-6}\end{array}$

We decided, therefore, to examine the effect of eserine on the non-choline ester hydrolysis brought about by our purified extracts, from which we believed the esterase had been removed (see section $1, a$ ).

Table 2 shows that small amounts of eserine inhibit the hydrolysis of acetylcholine and of non-
Hydrolysis (in $\mu \mathrm{l}$. $\mathrm{CO}_{2}$ evolved in

\begin{tabular}{|c|c|c|c|}
\hline \multirow{2}{*}{$\begin{array}{c}\text { Acetylcholine } \\
(0.003 M)\end{array}$} & \multirow{2}{*}{$\begin{array}{c}\text { Tributyrin } \\
(0.003 M)\end{array}$} & \multicolumn{2}{|c|}{$\%$ inhibition of hydrolysis of } \\
\hline & & Acetylcholine & Tributyrin \\
\hline $\begin{array}{c}66 \cdot 0 \\
42 \cdot 5 \\
9 \cdot 0 \\
0\end{array}$ & $\begin{array}{c}22.5 \\
15 \cdot 5 \\
2 \cdot 5 \\
0\end{array}$ & $\begin{array}{r}\overline{36} \\
86 \\
100\end{array}$ & $\begin{array}{r}\overline{31} \\
89 \\
100\end{array}$ \\
\hline $\begin{array}{r}39.5 \\
20.5 \\
7.0 \\
3.5\end{array}$ & $\begin{array}{r}12.5 \\
6.0 \\
2.5 \\
1.5\end{array}$ & $\begin{array}{l}-\overline{48} \\
82 \\
91\end{array}$ & $\begin{array}{l}-\overline{52} \\
80 \\
88\end{array}$ \\
\hline
\end{tabular}

if at all, the hydrolysis of tributyrin. Experimenting with various blood sera, Easson \& Stedman [1937] observed that addition of activities did occur in the presence of two substrates (tributyrin and butyryl choline), the addition being almost complete in the case of guinea-pig serum, partial in the case of horse serum and less pronounced in the case of human 
serum. Once more we are able to confirm these results for untreated sera and crude tissue extracts, and we again agree with Stedman's interpretation that the addition of activities is caused by a second enzyme, esterase, abundant in the sera of guinea-pig and horse.

If, however, purified preparations from which the esterase has been removed (see Section $1, b$ ) are allowed to act on a mixture of two substrates, a choline ester (acetylcholine) and a non-choline ester (tributyrin), no additive effect can be observed (Table 3).

Table 3. The hydrolysis of mixed substrates by purified 'cholinesterase' preparations

$\mu$ l. $\mathrm{CO}_{2}$ evolved in $5 \mathrm{~min}$. from

$\begin{array}{cccc}\begin{array}{c}\text { Source of } \\ \text { cholin-, } \\ \text { esterase' }\end{array} & \begin{array}{c}\text { Acetylcholine } \\ (0.03 M)\end{array} & \begin{array}{c}\text { Tributyrin } \\ (0.03 M)\end{array} & \begin{array}{c}\text { Acetylcholine } \\ (0.03 M)+ \\ \text { tributyrin } \\ (0.03 M)\end{array} \\ \begin{array}{c}\text { preparation } \\ \text { Serum }\end{array} & 105 & 34 & 100 \\ \left(Q_{\text {Ach }} 16,000\right) & & 13 & 42 \\ \text { Pancreas } & 42 & & \\ \left(Q_{\text {Ach }} 600,000\right) & & & \end{array}$

This result is consistent with our assumption that the hydrolysis of choline esters in serum and certain tissues is brought about by an enzyme also capable of hydrolysing non-choline esters.

We have presented and discussed three types of evidence in support of our hypothesis that one enzyme is the agent for the hydrolysis of choline and non-choline esters in our purified 'cholinesterase' preparations.

(a) the unaltered $Q_{\mathrm{Ach}} / Q_{\text {non-ChE }}$ ratio within the range of hundred-fold to two thousand-fold purification;

(b) the identical inhibitory effect of eserine on choline ester and non-choline ester hydrolysis, when 'cholinesterase' alone is present;

(c) the complete lack of addition of activities when a choline and a non-choline ester are hydrolysed together.

The concurrence of these three different lines of evidence can, we believe, be accepted as conclusive proof that the 'cholinesterase' in horse serum and dog pancreas is a non-specific enzyme.

The term cholinesterase, suggestive of substrate specificity, should, therefore, not be applied to the non-specific enzymes in sera and certain tissues and might be replaced by the term pseudo-cholinesterase.

\section{THE SPECIFIC OR TRUE CHOLINESTERASE}

Extending our studies on the specificity of cholinesterase to other mammalian tissues, we discovered in red blood cells and brain tissue of various species a true cholinesterase, acting exclusively on choline esters.
Cholinesterase in red blood cells. Table 4 shows that laked red blood cells are capable of hydrolysing both acetylcholine and non-choline esters, such as tributyrin and methyl butyrate. By a simple method of purification (see Appendix) blood cell extracts were obtained, displaying increased activity per unit weight towards acetylcholine, while being completely inactive towards tributyrin and methyl butyrate (Table 4).

Table 4. The activity, before and after purification, of cholinesterase in red blood cells towards choline and non-choline esters

\begin{tabular}{|c|c|c|c|c|c|c|}
\hline \multirow[b]{2}{*}{$\begin{array}{l}\text { Source of } \\
\text { red blood } \\
\text { cells }\end{array}$} & \multicolumn{2}{|c|}{$Q_{\mathrm{Ach}}$} & \multicolumn{2}{|c|}{$Q_{\mathrm{Tb}}$} & \multicolumn{2}{|c|}{$Q_{\mathbf{y b}}$} \\
\hline & $\begin{array}{l}\text { Before } \\
\text { purifi- } \\
\text { cation }\end{array}$ & $\begin{array}{l}\text { After } \\
\text { purifi- } \\
\text { cation }\end{array}$ & $\begin{array}{l}\text { Before } \\
\text { purifi- } \\
\text { cation }\end{array}$ & $\begin{array}{l}\text { After } \\
\text { purifi- } \\
\text { cation }\end{array}$ & $\begin{array}{l}\text { Before } \\
\text { purifi- } \\
\text { cation }\end{array}$ & $\begin{array}{l}\text { After } \\
\text { purifi } \\
\text { cation }\end{array}$ \\
\hline Human & $23 \cdot 0$ & 440 & $5 \cdot 4$ & 0 & 2.5 & 0 \\
\hline Sheep & $11 \cdot 5$ & 183 & $6 \cdot 5$ & 0 & $2 \cdot 0$ & 0 \\
\hline Horse & $7 \cdot 0$ & 178 & $2 \cdot 6$ & 0 & - & - \\
\hline $\mathrm{Ox}$ & $19 \cdot 5$ & 340 & $3 \cdot 0$ & 0 & - & - \\
\hline
\end{tabular}

These experiments, we believe, justify the conclusion that a specific cholinesterase is present in the red blood cells of various mammals.

Cholinesterase in brain. Brain tissue (mouse, dog), which effectively hydrolyses acetylcholine, exhibits some activity towards tributyrin and tripropionin, but apparently none towards methyl butyrate (Table 5). Unfortunately, brain cholinesterase does not lend itself readily to purification, and has not yet been separated from the other esterases present in brain tissue.

Nevertheless, the effect of eserine on the choline and non-choline ester hydrolysis, brought about by brain tissue, and the action of brain tissue on mixed substrates, enable us to arrive at a definite conclusion regarding the specificity of the cholinesterase in brain. Similar experiments with certain other unpurified esterase preparations, e.g. guinea-pig serum or crude pancreas extracts, would have been inconclusive, since the hydrolysis of non-choline esters by these preparations, far exceeding the hydrolysis of acetylcholine, would have concealed the presence of pseudo-cholinesterase (see Section 1,b). No such interference, however, occurs in experiments with crude brain preparations, owing to the fact that brain tissue, with rare exceptions, hydrolyses choline esters far more readily than non-choline esters.

\section{(a) The effect of eserine on choline and non-choline ester hydrolysis brought about by brain tissue}

Table 5 shows that an amount of eserine which almost completely inhibits the hydrolysis of acetylcholine has practically no effect on the hydrolysis of tributyrin. Indeed, the concentration of eserine must be increased more than hundred-fold before any appreciable inhibition is observed. 
Table 5. Effect of eserine on the hydrolysis of choline and non-choline esters by cholinesterase in brain

The brain tissue was ground and suspended in about 5 volumes of distilled water, centrifuged, and the precipitate containing the cholinesterase was again suspended in the same volume of water. $0.2 \mathrm{ml}$. of this suspension was employed in all experiments except the last set (Nucleus caudatus) where $0.05 \mathrm{ml}$. was used).

\begin{tabular}{|c|c|c|c|c|c|}
\hline \multirow{2}{*}{$\begin{array}{l}\text { Source of } \\
\text { cholin- } \\
\text { esterase }\end{array}$} & \multirow{2}{*}{$\begin{array}{l}\text { Molar } \\
\text { concen- } \\
\text { tration } \\
\text { of } \\
\text { eserine }\end{array}$} & \multicolumn{4}{|c|}{$\mu \mathrm{l} . \mathrm{CO}_{2}$ evolved in $10 \mathrm{~min}$. from } \\
\hline & & $\begin{array}{l}\text { Acetyl- } \\
\text { choline }\end{array}$ & $\begin{array}{c}\text { Tri- } \\
\text { butyrin }\end{array}$ & $\begin{array}{l}\text { Methyl- } \\
\text { butyrate }\end{array}$ & $\begin{array}{l}\text { Tripro- } \\
\text { pionin }\end{array}$ \\
\hline $\begin{array}{l}\text { Mouse brain } \\
\text { (whole) }\end{array}$ & $\begin{array}{l}0 \\
10^{-6} \\
10^{-5} \\
10^{-4}\end{array}$ & $\begin{array}{c}53 \cdot 0 \\
7 \cdot 0 \\
0 \\
0\end{array}$ & $\begin{array}{l}34 \cdot 0 \\
34 \cdot 0 \\
34 \cdot 0 \\
36 \cdot 0\end{array}$ & $\frac{0}{-}$ & - \\
\hline $\begin{array}{l}\text { Dog brain } \\
\text { (grey matter, } \\
\text { cortex) }\end{array}$ & $\begin{array}{c}0 \\
10^{-6} \\
10^{-5} \\
10^{-4}\end{array}$ & $\begin{array}{c}27 \cdot 5 \\
0 \\
0 \\
0\end{array}$ & $\begin{array}{l}34 \cdot 5 \\
- \\
33 \cdot 0 \\
35 \cdot 0\end{array}$ & $\frac{0}{-}$ & - \\
\hline $\begin{array}{l}\text { Dog brain } \\
\text { (white } \\
\text { matter) }\end{array}$ & $\begin{array}{l}0 \\
10^{-6} \\
10^{-5} \\
10^{-4}\end{array}$ & $\begin{array}{r}62 \cdot 0 \\
4 \cdot 0 \\
0 \\
\cdot \quad 0\end{array}$ & $\begin{array}{l}26 \cdot 0 \\
24 \cdot 5 \\
23 \cdot 5 \\
20 \cdot 0\end{array}$ & $\overline{-}$ & - \\
\hline $\begin{array}{l}\text { Dog brain } \\
\text { (grey matter, } \\
\text { Nucleus } \\
\text { caudatus) }\end{array}$ & $\begin{array}{c}0 \\
10^{-7} \\
10^{-6}\end{array}$ & $\begin{array}{c}92 \cdot 0 \\
8 \cdot 0 \\
0\end{array}$ & - & - & $\begin{array}{l}9 \cdot 0 \\
8 \cdot 0 \\
8 \cdot 0\end{array}$ \\
\hline
\end{tabular}

If one enzyme were responsible for the hydrolysis of acetylcholine and tributyrin-as was the case in experiments with purified enzyme preparations from serum and pancreas (Table 2)-small amounts of eserine would inhibit the hydrolysis of both esters to the same extent. The fact that a concentration of eserine, which completely inhibits the hydrolysis of acetylcholine, has little or no effect on the hydrolysis of tributyrin, shows that the enzyme responsible for the hydrolysis of acetylcholine has practically no share in the hydrolysis of non-choline esters and can, therefore, be regarded as a specific cholinesterase.

\section{(b) The action of brain tissue on mixed substrates}

Table 6 gives the results of two typical experiments in which a choline ester (acetylcholine) and a noncholine ester (tributyrin) are added to a suspension of ground brain tissue both separately and together. When the two substrates are added together, the hydrolytic action of the brain tissue is exactly equal to the sum of its separate actions on the choline and the non-choline ester respectively.

If a pseudo-cholinesterase, i.e. an enzyme capable of hydrolysing both substrates, were present, the activity of the brain tissue towards the substrate mixture would be less than the sum of the activities which were observed when the substrates were added separately.

The fact that complete addition of activities takes place, reveals the presence of at least two distinct ester-hydrolysing enzymes, and excludes the existence of a pseudo-cholinesterase in brain tissue.
Table 6. The hydrolysis of mixed substrates by suspensions of ground brain tissue

The suspensions were prepared as described in Table 5 . $\mu$ l. $\mathrm{CO}_{2}$ evolved in $5 \mathrm{~min}$. from

$\begin{array}{cccc}\begin{array}{c}\text { Cholin- } \\ \text { esterase }\end{array} & \begin{array}{c}\text { Acetylcholine } \\ (0.003 M)\end{array} & \begin{array}{c}\text { Tributyrin } \\ (0.003 M)\end{array} & \begin{array}{c}\text { Acetylcholine } \\ (0.003 M)+ \\ \text { tributyrin } \\ (0.003 M)\end{array} \\ \begin{array}{c}\text { preparation } \\ \text { Dog brain } \\ \text { (grey matter, }\end{array} & 68 & 6 & 74 \\ \begin{array}{c}\text { nucleus } \\ \text { caudatus) }\end{array} & & & \\ \begin{array}{c}\text { Mouse brain } \\ \text { (whole) }\end{array} & 36 & 12 & 48\end{array}$

The above experiments prove, we believe, that the cholinesterase in the brain of mammals is a specific enzyme.

The true cholinesterase, found in brain tissue and red blood cells, may also be present in other tissues not yet investigated. Even in tissues such as pancreas, in which, according to our experiments, the hydrolysis of acetylcholine seems to be entirely due to the action of a pseudo-cholinesterase, the presence of small amounts of true cholinesterase cannot be excluded.

\section{THE ACTIVITY OF CHOLINESTERASE AND PSEUDO-CHOLINESTERASE AT VARIOUS CONCENTRATIONS OF ACETYLCHOLINE}

The pseudo-cholinesterases in human and horse serum exhibit their maximum activities at acetylcholine concentrations of about 1.0 and $0.3 \%$ respectively [Glick, 1937; Stedman, 1935], concentrations far higher than could be expected to occur in the blood stream. At relatively low concentrations of acetylcholine, still too high, however, to be compatible with life, the pseudo-cholinesterases display only a fraction of their maximum activity. If, for instance, $300 \mathrm{mg}$. of acetylcholine are added to $100 \mathrm{ml}$. of horse serum $\left(38^{\circ}, p \mathrm{H} \mathrm{7 \cdot 4}\right)$, we find that the hydrolysis of $3 \mathrm{mg}$. of the substrate is a matter of no more than $20 \mathrm{sec}$; if, on the other hand, only $3 \mathrm{mg}$. of acetylcholine are added to $100 \mathrm{ml}$. of serum, $3 \mathrm{~min}$. are required for the hydrolysis of the same amount of substrate.*

Unlike pseudo-cholinesterase, the true cholinesterase, found in brain tissue and red blood cells, is far more effective at low concentrations of acetylcholine; indeed, the lower the substrate concentration, the greater the activity of the specific cholinesterase (Tables 7 and 8). It may be noted that recently, Alles \& Hawes [1940], continuing the work of Galehr \& Plattner [1928], made the interesting observation that human red blood cells,

* The activity-substrate concentration curve of the pseudo-cholinesterase from dog pancreas is almost identical with the curve of the pseudo-cholinesterase from horse serum. 
which according to our experiments contain the specific cholinesterase, were responsible for most of the action of whole blood on acetylcholine, when the substrate was present at low concentrations. They also found that high concentrations of acetylcholine inhibited the action of cholinesterase in human red blood cells. At the same time they noted differences between the serum cholinesterase, which we have found to be a pseudo-cholinesterase, and the cholinesterase present in red blood cells.

Table 7. Hydrolysis of acetylcholine by cholinesterase from red blood cells

The horse blood cells were purified in the manner described in the Appendix.

\begin{tabular}{|c|c|c|c|c|}
\hline \multirow{2}{*}{$\begin{array}{l}\text { Concentration of } \\
\text { acetylcholine } \\
\text { mg. } \%\end{array}$} & \multicolumn{4}{|c|}{$\begin{array}{l}\mu \mathrm{l} . \mathrm{CO}_{2} \text { evolved in the } 2 \text { min. period } \\
\text { following addition of substrates to } \\
\text { haemolysed blood cells of }\end{array}$} \\
\hline & Man & She & Horse & $0 x$ \\
\hline $500 \cdot 0$ & $10 \cdot 0$ & & $6 \cdot 0$ & $12 \cdot 5$ \\
\hline $50 \cdot 0$ & $17 \cdot 0$ & 25 & 19.5 & - \\
\hline $25 \cdot 0$ & - & $30 \cdot 0$ & 20.5 & $28 \cdot 0$ \\
\hline $2 \cdot 5$ & $19 \cdot 0$ & - & $24 \cdot 0$ & $32 \cdot 0$ \\
\hline
\end{tabular}

Table 8. Hydrolysis of acetylcholine by cholinesterase in brain

The brain suspensions were prepared as described in Table 5.

$\mu$ l. $\mathrm{CO}_{2}$ evolved in the $2 \mathrm{~min}$. period following addition of substrates to suspensions of

$\begin{array}{cccc}\begin{array}{c}\text { Concentration of } \\ \begin{array}{c}\text { acetylcholine } \\ \text { mg. } \%\end{array}\end{array} & \begin{array}{c}\text { Mouse brain } \\ \text { (whole) }\end{array} & \begin{array}{c}\text { Dog brain } \\ \text { (grey matter, } \\ \text { cortex) }\end{array} & \begin{array}{c}\text { Dog brain } \\ \text { (whole) }\end{array} \\ 500.0 & 5.0 & 4.5 & 4.0 \\ 50.0 & - & 11.0 & 8.0 \\ 25.0 & 13.0 & - & 11.0 \\ 12.5 & 19.0 & 14.0 & - \\ 5.0 & 21.0 & 16.5 & - \\ 2.5 & 22.5 & 18.5 & -\end{array}$

Since it seems reasonable to assume that usually low concentrations of acetylcholine occur in living organisms, it is most likely that the destruction of acetylcholine, wherever it takes place rapidly, is brought about mainly, if not exclusively, by the specific cholinesterase.

\section{SUMMARY}

Experiments performed with highly purified esterase preparations capable of hydrolysing acetylcholine, show that the 'cholinesterase' present in blood serum and certain tissues is a non-specific enzyme, catalysing the hydrolysis not only of choline esters but of non-choline esters as well.

A specific cholinesterase, however, acting exclusively on choline esters, was found in the brain tissue and the red blood cells of some mammals.

The non-specific 'cholinesterase', purified from horse serum and dog pancreas, exhibits its maximum activity at high concentrations of acetylcholine (above $300 \mathrm{mg} . / 100 \mathrm{ml}$.) and only slight activity at low substrate concentrations. The reverse is true for the specific cholinesterase, found in brain tissue and red blood cells: while inhibited by high concentrations of acetylcholine, it displays its maximum activity at low substrate concentrations (below $3 \mathrm{mg} . / 100 \mathrm{ml}$.).

It is proposed to name the non-specific enzyme pseudo-cholinesterase, and to reserve the term cholinesterase for the specific enzyme.

\section{APPENDIX \\ Method for the separation of cholinesterase from other esterases in red blood cells}

10-15 ml. of freshly drawn oxalated blood (human, horse, sheep, ox) are centrifuged, and the plasma is discarded. The red blood cells are washed twice with about $30 \mathrm{ml}$. of physiological saline solution. A layer of white blood cells which forms on top of the red blood cells after centrifuging, is removed as completely as possible, by suction with a capillary.

To $5 \mathrm{ml}$. of the washed red blood cells $45 \mathrm{ml}$. of distilled water are added. When complete haemolysis has taken place, the solution is shaken thoroughly with $1 \mathrm{~g}$. of kieselguhr (B.D.H., acid-washed). The mixture, including all the kieselguhr, is then filtered through filter paper on a Büchner funnel, $7 \mathrm{~cm}$. in diameter. The filtrate, containing practically all the haemoglobin, is poured back, until it is absolutely clear, and is then discarded. The almost-dry filter cake is scraped from the filter paper, thoroughly shaken with $50 \mathrm{ml}$. of distilled water and the filtration repeated as previously described.

The filter cake is again scraped from the filter paper and suspended in $5 \mathrm{ml}$. $N / 1000 \mathrm{NaOH}$. The suspension is shaken thoroughly for a few minutes and then centrifuged at high speed.

The slightly turbid supernatant fluid, orange-red in colour, is 20-30 times as active (per unit dry weight) as the original blood cells towards acetylcholine, and inactive towards non-choline esters, such as tributyrin.

\section{REFERENCES}

Alles, G. A. \& Hawes, R. C. [1940]. J. biol. Chem. 133, 375. Dale, H. H. [1914]. J. Pharmacol. 6, 147.

Easson, L. H. \& Stedman, E. [1937]. Biochem. J. 31, 1723. Galehr, O. \& Plattner, F. [1928]. Pflüg. Arch. ges. Physiol. 218, 488.

Glick, D. [1937]. Biochem. J. 31, 521.

Loewi, O. \& Navratil, E. [1926]. Pflüg. Arch. ges. Physiol. 214, 678 .
Mendel, B. \& Mundell, D. B. [1943]. Biochem. J. 37, 64.

Stedman, E. [1935].

Stedman, E., Stedman, E. \& Easson, L. H. [1932]. Biochem. J. 26, 2056.

Stedman, E. \& Stedman, E. [1935]. Biochem. J. 29, 2107.

Vahlquist, B. [1935]. Skand. Arch. Physiol. 72, 133. 